\title{
STRUCTURE OF THE RAVNS STOR $\varnothing$ AMPHIBOLITE BELT IN THE FISKENÆSSET REGION
}

\author{
Lars Skov Andersen and Clark Friend
}

\begin{abstract}
Introduction
The Ravns Stor $\varnothing$ belt of metamorphosed plutonic and volcanic rocks is situated on the northern side of Frederikshåbs Isblink (see map plate 1). Its strike varies from NNE to ENE, and it dips steeply towards the SE. The exposed part of the belt is $25 \mathrm{~km}$ long with a maximum thickness of $4 \mathrm{~km}$.
\end{abstract}

\section{Previous work}

The rocks of the belt were first mentioned in the diary of K. L. Giesecke (1910), who noted the garnet megacrysts on Ikátup nunâ, "welche oft die Grösse einer Mannsfaust haben", and which have later been described by Dawes (1970). In 1879 , the belt was accurately positioned as a NE-trending tract of "Glimmerog Talkskifer" on a reconnaissance map by Kornerup (1879). Recent work includes several papers by Windley $(1966,1968,1969$; Windley et al., 1966; and Windley \& Bridgwater, 1971) and a single report by Dawes (1969).

According to Windley (op. cit). the belt consists of supracrustal volcanics, which during the youngest tectonic event of the region were synformally down-folded or down-sheared into older gneissic basement with a granulite facies mineralogy. The down-folding or down-shearing took place in a linear belt, within which the adjacent older gneisses recrystallised developing a new foliation under the conditions of amphibolite facies metamorphism. In the most recent work where the belt is mentioned (Windley \& Bridgwater, 1971) it is interpreted as the root zone of a major greenstone belt.

\section{Rock types}

The main rock types of the belt are medium- to coarse-grained, basic to intermediate amphibolites, which often possess a garbenshiefer texture. This texture is typical of volcanic tuffs subjected to post-tectonic metamorphism (Spry, 1967). Massive and fissile greenschists, which appear to represent volcanic lava flows 
and ash layers respectively, and lenses of ultrabasic rocks form only a minor part of the succession. The ultrabasic rocks are concentrated along the south-eastern margin of the belt. Towards both ends of the belt the garbenschiefer texture of the amphibolites is replaced by a xenoblastic granular texture, and the rocks have the appearance of typical 'basement amphibolites'. Rocks of similar appearance have been traced towards the north by Tomas and Williams (see map plate 1).

In the greenschists and the intermediate amphibolites, pillow structures are locally well preserved and bear witness to a supracrustal origin for these rocks. Within these supracrustal rocks layers of apparently intrusive igneous origin also occur, chiefly as a single unit $1.5 \mathrm{~km}$ thick. This unit is composed of three main lithologies which are repeated three or four times. The first is a mafic amphibolite, which contains plagioclase crystals commonly between 2 and $3 \mathrm{~cm}$ across concentrated in bands 10 to $20 \mathrm{~cm}$ thick. This is overlain by a gabbroic layer, which possesses rhythmic layering shown by layers 15 to $20 \mathrm{~cm}$ thick, in which a hornblenderich base 2 to $3 \mathrm{~cm}$ thick grades into a plagioclase-rich top of similar thickness. The third main type of layer which occurs in the unit is gabbroic to leucogabbroic in appearance. It is mainly homogeneous and garnet-bearing, but contains some rusty weathering horizons. This $1.5 \mathrm{~km}$ thick unit grades thus from mela-to leucogabbro, and although sharp boundaries have not been observed because of the later deformation, the unit is considered to be a sill-like intrusion. Similar primary igneous structures have been found by Dawes (1969 \& 1970b) on Dalagers Nunatakker.

\section{Deformation and metamorphism}

In contrast to earlier opinion the rocks of the belt can be shown to have undergone several phases of deformation and metamorphism. The importance of early deformation $\left(D_{1}\right)$ is uncertain, as only small-scale folds are preserved. After this the rocks in the centre of the belt suffered static recrystallisation under conditions of greenschist-amphibolite transitional facies. Later only minor recrystallisation affected the rocks in the centre of the belt, whereas the metamorphic grade appears to have increased towards both the margins and the ends of the belt, and was accompanied by three major phases of deformation $\left(D_{2}, D_{3}\right.$ and $\left.D_{4}\right)$.

The main foliation trends NE, parallel to the margins of the belt, and is attributed to the first major phase of deformation $\left(D_{2}\right)$, before or during which the belt acquired its present position as a sheet or layer of amphibolite surrounded by gneisses on either side. In the centre of the belt major $F_{2}$ folds are preserved and the lithological layering is to a large extent oblique to the foliation. In the marginal zones, however, the foliation is so intense that it is impossible to recognize the original lithological succession. In the south-western part of the belt the lithological layering is dominantly parallel to the foliation and no hinge zones of $F_{2}$ folds have so far been found. 
The belt has been intruded by sheets of hornblende-biotite tonalite and associated garnet-muscovite granites along parts of its south-east margin. These sheets seem to have been emplaced parallel with the NE foliation but they also possess this foliation themselves. Outside the belt, the tonalites contain lenses of amphibolite so it appears that only part of the amphibolite succession is found within the belt, but it is not certain whether the disruption of the outer part was caused by deformation, by tonalite intrusion or by a combination of both.

During the second and third main phases of deformation $\left(D_{3}\right.$ and $\left.D_{4}\right)$, the principal stresses were orientated at a low angle to the belt, but because the rock units in the centre of the belt are thick, no small folds developed there. Towards the ends of the belt small- and medium-scale over-turned $F_{8}$ folds developed, with axial planes gently inclined toward the south and varying in strike between NE and ESE. The variation is due to reorientation by the last major deformation $\left(D_{4}\right)$, which has steep to vertical SE-trending axial planes.

The overturned minor folds are apparently parasitic to a major $F_{3}$ synform of which the well preserved part of the belt constitutes the steep southern limb. The northern flat-lying limb of the fold is represented by a thin layer of ordinary 'basement amphibolites'. The hinge of this fold is exposed to the north-east, where the belt turns to the north-west as observed by Dawes (1969). This is opposite to the ESE trend indicated by Windley et al. (1966), Windley (1969), and shown on the Tectonic/Geological Map of Greenland (GGU, 1970).

\section{Relation to the gneisses}

The NE trend of the belt and adjacent gneisses, earlier considered to be due to the youngest tectonic event of the region (Windley, 1969), is rather an old feature which is preserved because of the relatively thick belt of competent rocks. Furthermore this NE trend pre-dates the formation of (par)autochthonous granodiorites (Hopgood, this issue p. 23), which constitute a large part of the gneiss terrain to the east and south-east of the belt (see map plate 1). This leaves only the 'streaky' gneisses as a possible gneissic basement to the amphibolites, but no intrinsic evidence was found in them to support this theory. To the north amphibolites which apparently correlate with the Ravns Storø belt contain layers of the same type of anorthosite that in the vicinity of Fiskenæsset pre-dates a granulite facies metamorphism.

\section{Age and regional implications}

Preliminary data give a zircon concordia age of $3030 \pm 20 \mathrm{~m}$. y. (Pidgeon, this issue) for a sample of autochthonous granodiorite. This can presumably be regarded as an upper age of the amphibolites. 
The age and evolution of the Ravns Stor $\varnothing$ belt has much in common with the Malene Supracrustals of the Godthåb area (McGregor, 1973), but in the Ravns Stor $\varnothing$ area there is as yet no intrinsic evidence of rocks similar to the Amitsoq gneisses, which could have formed a basement to the volcanics. Furthermore, the age of the Ravns Stor $\varnothing$ belt, the preservation of primary igneous structures and textures and its relationship with tonalites and high-grade gneisses is reminiscent of the ancient greenstone belts described by Anhaeusser et al. (1968). Application of this model is clearly attractive, as Windley \& Bridgwater (1971) found in equating the Ravns Stor $\varnothing$ belt with the root zone of a major greenstone belt. However, it now seems more likely, that the Ravns Stor $\varnothing$ belt represents a particularly well preserved remnant of the amphibolite layers, which occur throughout the Fiskenæsset area. If this is correct the Ravns Stor $\varnothing$ belt may have been part of an originally much larger, perhaps once continuous, supracrustal unit and thereby provide an example of these ancient amphibolites in another setting to that of the synclinal basin suggested by Anhaeusser et al. (1968).

\section{References}

Anhaeusser, C. R., Roering, C., Viljoen, M. J. \& Viljoen, R. P. 1968: The Barberton Mountain Land: A model of the elements and evolution of an Archaean fold belt. Geol. Soc. S. Afr. Annex 71, 225-254.

Dawes, P. R. 1969: Age and correlation of supracrustal rocks in the Frederikshåbs Isblink area. Rapp. Grønlands geol. Unders. 19, 31-33.

Dawes, P. R. 1970a: Grønlandske granater som smykkesten. Grønland 1970, 113-119.

Dawes, P. R. 1970b: Bedrock geology of the nunataks and semi-nunataks in the Frederikshåbs Isblink area. Rapp. Grønlands geol. Unders. 29.

GGU 1970: Tectonic/Geological Map of Greenland. Scale 1:2 500000.

[Giesecke, K. L.] 1910: Karl Ludwig Gieseckes mineralogisches Reisejournal über Grönland, 1806-1813. Meddr Grønland 35.

Kornerup, A. 1879: Geologiske Iagttagelser fra Vestkysten af Grønland (62 $15^{\circ}-64^{\circ} 15^{\prime}$ N.B.). Meddr Grønland 1, 77-139.

McGregor, V. R. 1973: The early Precambrian gneisses of the Godthåb district, West Greenland. Phil. Trans. R. Soc. Lond. A, 273, 343-358.

Spry, A. 1969: Metamorphic textures. Oxford: Pergamon Press.

Windley, B. F. 1966: Anorthosites and polymetamorphism between Ravns Storø and Sukkertoppen, West Greenland. Rapp. Grønlands geol. Unders. 11, 27-29.

Windley, B. F. 1968: New field relations from the early Precambrian of West Greenland. Rapp. Grønlands geol. Unders. 15, 27-31.

Windley, B. F. 1969: Evolution of the early Precambrian basement complex of southern West Greenland. Spec. Pap. Geol. Ass. Canada 5, 155-161.

Windley, B. F. \& Bridgwater, D. 1971: The evolution of Archaean low- and high-grade terrains. Spec. Publs. geol. Soc. Aust. 3, 33-46.

Windley, B. F., Henriksen, N., Higgins, A. K., Bondesen, E. \& Jensen, S. B. 1966: Some border relations between supracrustal and infracrustal rocks in South-West Greenland. Rapp. Gronlands geol. Unders. 9. 